\title{
REVIEW ON KEY PARAMETERS DURING CARBOTHERMIC REDUCTION OF TIN FROM CASSITERITE
}

\author{
Michel Kalenga WA KALENGA \\ University of Johannesburg, Faculty of Engineering and the Built Environment, School of Mining, Metallurgy \\ and Chemical Engineering, Johannesburg, South Africa, michelk@uj.ac.za
}

https://doi.org/10.37904/metal.2021.4246

\begin{abstract}
Due to the sudden sharp increase in tin demand, the production of tin through carbothermic reduction process requires refreshment by assembling important required data and disseminate to the potential producers. The current paper presents a review on different parameters that have been tested on different tin ores. Basicity, although simply defined as ratio between the basic oxides and acidic oxides, more information unfolds depending on whether the basic oxides or acidic oxides can be interchanged or replaced by another. The effects of interchanging a basic oxide by another on the kinetics and the slag composition and behaviors are discussed in the current paper. Since different ores have different compositions the adjustment of basicity may require different basic or acidic oxides. Different effects of such parameters on the carbothermic reduction of tin are here gathered and discussed.
\end{abstract}

Keywords: Metallurgy, carbothermic reduction, tin

\section{INTRODUCTION}

The current high demand of tin and its accompanying metals $\mathrm{Nb}$ and Ta due to HighTech has revived the metallurgy of tin. The smelting of tin is essentially based on the carbothermic reduction. However, cassiterite being the main mineral carrying tin under oxide form has different composition depending on where it is mined. The most economic mineral in $\mathrm{Sn}$-bearing ore is cassiterite $\left(\mathrm{SnO}_{2}\right)$. Sn production has increased for the past 30 years and 300000 tons per annum are produced in last years [1,2]. Prediction studies dictate that in the forthcoming years, the demand will be increased at a rate of $2 \%$ per annum for the next 5-10 years [1,3]. Sn is primarily produced from cassiterite ores and secondary sources (reprocessed materials) through the conventional mining, mineral processing and smelting processes. Conventional Sn smelting processes include use of air draught, reverberatory and electric arc furnaces which have the disadvantages of high smelting temperatures, long smelting time and high tin loss ratio (>10 wt\%) [2]. Currently, $\mathrm{Sn}$ is efficiently recovered from its minerals by a carbothermic reduction process [1]. Several researchers have investigated on the reduction of cassiterite using a diverse of fluxing agents such as Silica and Lime [2]. The reduction of cassiterite may take place in the presence of gases such as $\mathrm{CO}$ and $\mathrm{H}_{2}$ adjusted in a given ratio to promote the Boudouard reaction $\left(\mathrm{C}+\mathrm{CO}_{2} \rightarrow 2 \mathrm{CO}\right)$ and favour the reduction of $\mathrm{SnO}_{2}$ to a $\mathrm{Sn}$ metal. For better overall recovery of tin, comminution followed by concentration is required to upgrade the run of mine. Some ores do contain valuable by-products, therefore a pre-concentration would be required.

\subsection{Pre-concentration of cassiterite ore bearing $\mathrm{Nb}-\mathrm{Ta}$ minerals}

Several equipments were used to concentrate Sn oxide. A shaking, sometimes associated with the spiral as a complementary equipment used for secondary concentration [4].

For a better pre-concentration, the following parameters must be optimized: inclination of the table, Stroke length, feed rate and water flow. The effect of shaking table on the beneficiation of cassiterite ore bearing 
magnetite located on the eastern part of Egypt revealed that best separation was achieved when inclination of the table (4.13 degree), Stroke length $(2.5 \mathrm{~cm})$, feed rate $(307.6 \mathrm{gm} / \mathrm{min})$, and water flow rate $(24.22 \mathrm{l} / \mathrm{min})$. A concentrate having a grade of $13.2 \mathrm{wt} \% \mathrm{SnO}_{2}$ at a recovery of $86.2 \%$ by weight was achieved [5].

The presence of some oxides impacts negatively the recovery of tin and its physical properties. It is imperatively advised to design a smelting process where $\mathrm{Sn}$ is free of iron. Therefore, the removal of iron is very necessary during the extraction process.

\subsection{Main reactions during tin carbothermic reduction}

The different successive reactions that occur during carbothermic reductions are described as follows:

$$
\begin{aligned}
& 3 \mathrm{SnO}_{2}(\mathrm{~s})+2 \mathrm{C}(\mathrm{s})=\mathrm{Sn}_{3} \mathrm{O}_{4}(\mathrm{~s})+2 \mathrm{CO}(\mathrm{g}) \\
& 3 \mathrm{SnO}_{2}(\mathrm{~s})+2 \mathrm{CO}(\mathrm{g})=\mathrm{Sn}_{3} \mathrm{O}_{4}(\mathrm{~s})+2 \mathrm{CO}_{2}(\mathrm{~g}) \\
& \mathrm{Sn}_{3} \mathrm{O}_{4}(\mathrm{~s})+\mathrm{CO}(\mathrm{g})=3 \mathrm{SnO}(\mathrm{s})+\mathrm{CO}_{2}(\mathrm{~g})
\end{aligned}
$$

The combination of reactions (2) and (3) leads to reaction (4a) or reaction (4b) below:

$$
\begin{aligned}
& 3 \mathrm{SnO}_{2}(\mathrm{~s})+3 \mathrm{CO}(\mathrm{g})=3 \mathrm{SnO}(\mathrm{s})+3 \mathrm{CO}_{2}(\mathrm{~g}) \\
& \mathrm{SnO}_{2}(\mathrm{~s})+\mathrm{CO}(\mathrm{g})=\mathrm{SnO}(\mathrm{s})+\mathrm{CO}_{2}(\mathrm{~g}) \\
& \mathrm{SnO}(\mathrm{s})+\mathrm{CO}(\mathrm{g})=\mathrm{Sn}(\mathrm{l})+\mathrm{CO}_{2}(\mathrm{~g}) \\
& \mathrm{C}(\mathrm{s})+\mathrm{CO}_{2}(\mathrm{~g})=2 \mathrm{CO}(\mathrm{g})
\end{aligned}
$$

With reaction (6) being the Boudouard reaction. It is known that the exothermicity of reduction reactions decrease with the valance of the metal. It is therefore, important to mention that from reaction (1) down to reaction (5) the heat released decreased.

\section{EFFECTS OF DIFFERENT PARAMETERS}

\subsection{Effect of $\mathrm{FeO} / \mathrm{SnO}$ ratio}

Tin smelting occurs in two cycles namely primary and secondary cycle. In the primary cycle, cassiterite concentrates are smelted through carbothermic reduction. A crude tin and a slag are produced. The activity of $\mathrm{FeO}$ in the slag produced is lower than that of $\mathrm{SnO}$. However, under strong reducing conditions $\mathrm{FeO} / \mathrm{SnO}$ ratio can be increased leading to an increased Fe content in the metal. Recommendations are that the cooling rate be controlled to allow the hard tin to be concentrated at a specific point based on difference in temperatures as a driving force of purification [6]. The correlation between $\mathrm{FeO}$ and $\mathrm{SnO}$ in the slag is illustrated in Figure 1 below. It transpires that $\mathrm{SnO}$ in the primary slag is inverse proportional to $\mathrm{FeO}$ in the slag. The optimum composition is said to be in the range of 30 to $40 \% \mathrm{FeO}$ [6]. $\mathrm{FeO}$ and $\mathrm{SnO}$ are playing the role of fluxes.

The secondary cycle makes use of the primary cycle slag in addition to a reducing agent and $\mathrm{CaO}$ as a flux. The amount of $\mathrm{CaO}$ is limited to reduce the volume of the final slag since the volume of the reactor is limited. During carbothermic reduction of the primary slag, $\mathrm{SnO}$ and $\mathrm{FeO}$ are reduced to lower amounts.

In the secondary slag, $\mathrm{SnO}$ and $\mathrm{FeO}$ directly proportional which is opposite to the primary slag. When FeO increases, $\mathrm{SnO}$ increases though the proportionality is not as close as in the primary slag. An increase of 10 $\mathrm{wt} \%$ of $\mathrm{FeO}$ leads to an increase of close to $2 \mathrm{wt} \%$ of SnO. However, an increase of $10 \mathrm{wt} \%$ of $\mathrm{FeO}$ in the primary slag leads to a decrease of more than $15 \%$ of $\mathrm{SnO}$.

Besides the fact that this Sn smelting process has found success in the smelting industries, it had limitations of long smelting time and high operating temperature which make the process costly and high losses of $\mathrm{Sn}$ in the slag fraction. Some innovative approaches have been tested. 


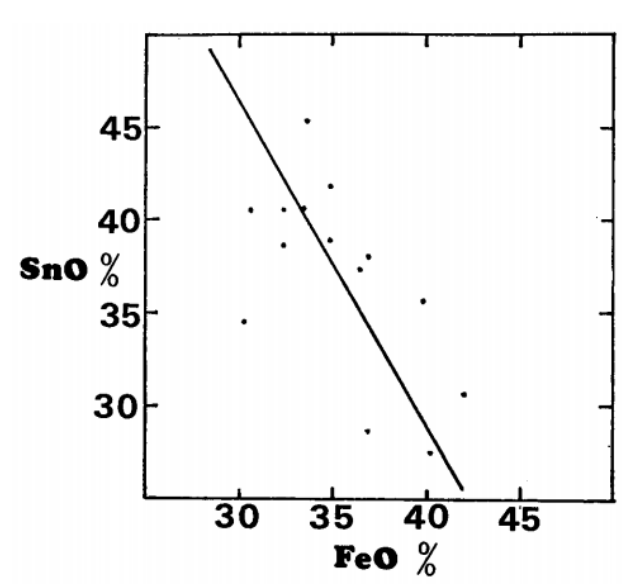

(a)

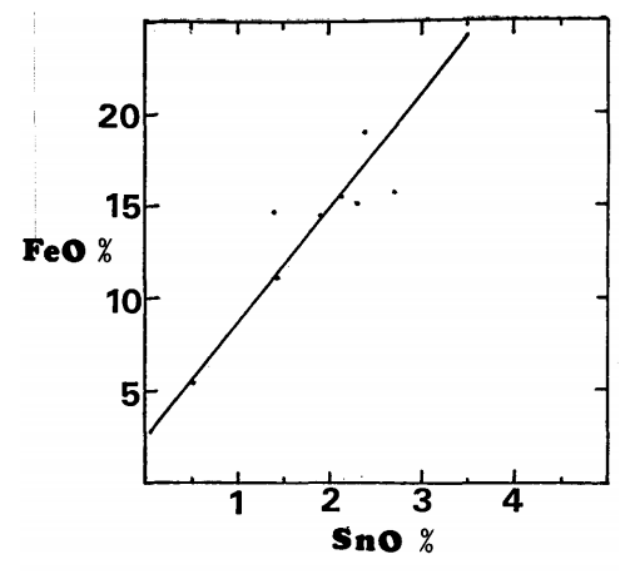

(b)

Figure 1 Relationship between $\mathrm{SnO}$ and $\mathrm{FeO}$ in the primary and secondary slags [6]

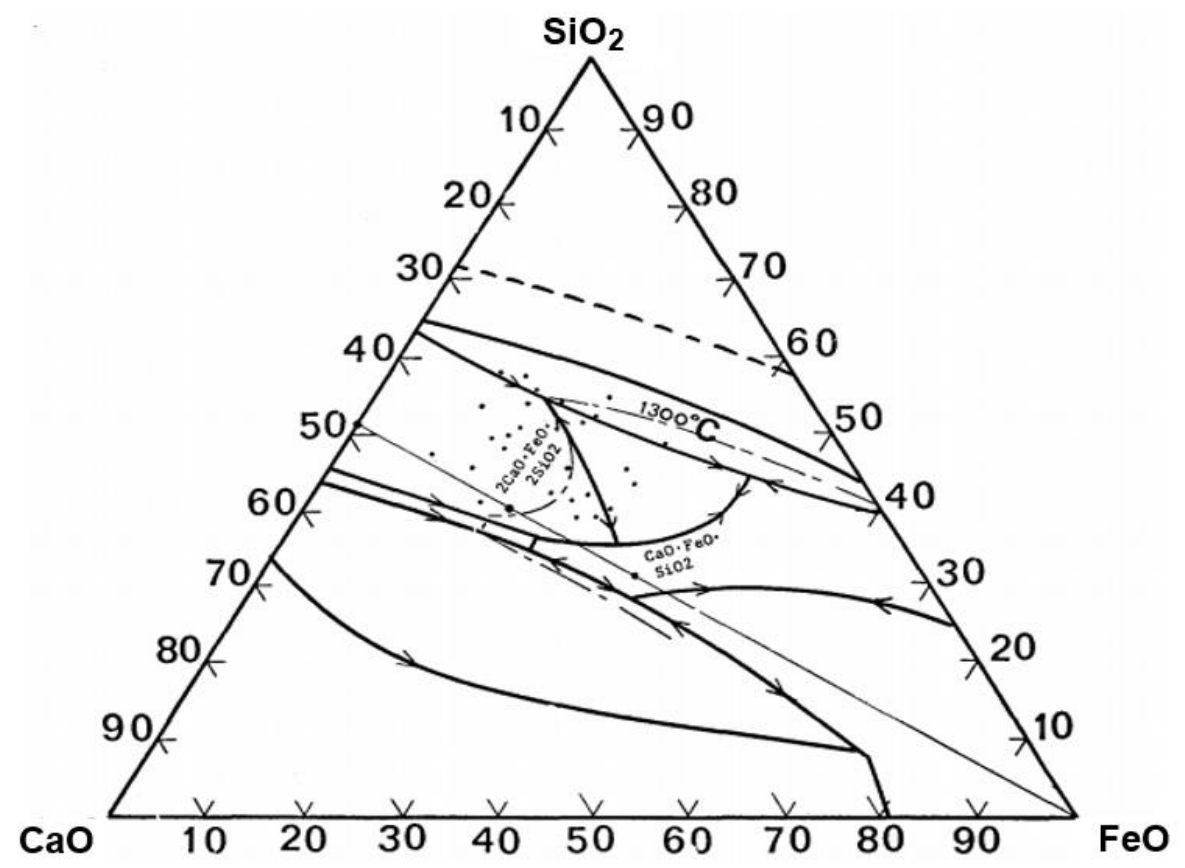

Figure 2 Ternary diagram $\mathrm{CaO}-\mathrm{SiO}_{2}-\mathrm{FeO}$ [6]

The ternary diagram in Figure 2 provides enough information on the influence of $\mathrm{CaO} / \mathrm{SiO}_{2}$ ratio. It transpires that around $1300^{\circ} \mathrm{C}$, typical composition of the slag produced in the secondary is indicated around the liquidus line. It also shows the importance of $\mathrm{CaO}-\mathrm{SiO}_{2}$ ratio on the activities of $\mathrm{FeO}$ and $\mathrm{SnO}$. This implies that for a low alumina and low $\mathrm{MgO}$ concentrate, the above ternary diagram can be of great contribution to predict and understand the quality of products during tin smelting.

\subsection{Effect of roasting on Sn recovery}

An innovative approach to extract metallic $\mathrm{Sn}$ from cassiterite ore in presence of $\mathrm{Na}_{2} \mathrm{CO}_{3}$ was used in 2 steps [2]. The cassiterite ore was exposed to reduction roasting in the presence of $\mathrm{Na}_{2} \mathrm{CO}_{3}$ followed by waterleaching. During the reduction roasting, a huge amount of $\mathrm{Sn}$ metal was formed from $\mathrm{SnO}_{2}$ while some of $\mathrm{SnO}_{2}$ reacted with $\mathrm{Na}_{2} \mathrm{CO}_{3}$ to form a $\mathrm{Na}_{2} \mathrm{SnO}_{3}$ which is easily reduced to metallic $\mathrm{Sn}$. Reactions involved during the whole process are summarized by the equation (7) to (13). About $98.1 \mathrm{wt} \%$ of the total $\mathrm{Sn}$ was recovered while 
roasting at $950{ }^{\circ} \mathrm{C}$ with a carbon content of $80 \%$ of purity, for 120 minutes with a dosage of $30 \%$ of $\mathrm{Na}_{2} \mathrm{CO}_{3}$ according to the relationship $\left(\mathrm{Na}_{2} \mathrm{CO}_{3} /\left(\mathrm{SnO}_{2}+\mathrm{SiO}_{2}\right)\right.$.

$$
\begin{aligned}
& \mathrm{SnO}+\mathrm{Sn}=2 \mathrm{SnO} \\
& \mathrm{SnO}+\mathrm{SiO}_{2}=\mathrm{SnO} \cdot \mathrm{SiO}_{2}
\end{aligned}
$$

Reduction in the presence of $\mathrm{Na}_{2} \mathrm{CO}_{3}$

$$
\begin{aligned}
& \mathrm{SnO}_{2}+\mathrm{Na}_{2} \mathrm{CO}_{3}=\mathrm{Na}_{2} \mathrm{SnO}_{3}+\mathrm{CO}_{2} \\
& \mathrm{SnO}+\mathrm{Na}_{2} \mathrm{CO}_{3}=\mathrm{Na}_{2} \mathrm{SnO}_{3}+\mathrm{CO} \\
& \mathrm{Na}_{2} \mathrm{SnO}_{3}+2 \mathrm{CO}=\mathrm{Sn}+\mathrm{Na}_{2} \mathrm{CO}_{3}+\mathrm{CO}_{2} \\
& \mathrm{SiO}_{2}+\mathrm{Na}_{2} \mathrm{CO}_{3}=\mathrm{Na}_{2} \mathrm{SiO}_{3}+\mathrm{CO}_{2} \\
& 2 \mathrm{Na}_{2} \mathrm{CO}_{3}+\mathrm{SnO}_{2} \mathrm{SiO}_{2}=\mathrm{Na}_{2} \mathrm{SiO}_{3}+\mathrm{Na}_{2} \mathrm{SnO}_{3}+\mathrm{CO}
\end{aligned}
$$

\subsection{Effect of $\mathrm{Fe}_{3} \mathrm{O}_{4}$ on reduction smelting of cassiterite}

In case the cassiterite ore contains $\mathrm{Fe}_{3} \mathrm{O}_{4}$, the impact on $\mathrm{Sn}$ recovery in addition to the smelting temperature, time and the reducing agent, is the possible formation of Fe-Sn spinel during roasting [7]. However, this spinel can be reduced to $S n$ metal by smelting with strong reducing conditions. In case of weak reducing conditions, without changing the smelting time, the Sn metal may be formed whilst the increase in temperature plays a significant role for the formation rate $\mathrm{Fe}-\mathrm{Sn}$ spinel. The amount of magnetite presented in a sample has a remarkable effect on the formation of new phases bearing $\mathrm{SnO}_{2}$. The $\mathrm{Sn} / \mathrm{Fe}$ ratio in the spinel is directly proportional to the cassiterite/magnetite mass ratio [7].

\subsection{Effect of basicity during reduction smelting of cassiterite}

The basicity is always a useful parameter that govern the behavior of the slag. A basicity increases through addition of $\mathrm{CaO}$ and $\mathrm{MgO}$ while keeping $\mathrm{MgO}$ or keeping $\mathrm{CaO}$ constant plays an important role. The phases that form in the slag to preferentially collected $\mathrm{Nb}$ an $\mathrm{Ta}$ are similar when $\mathrm{CaO}$ and $\mathrm{MgO}$ are kept constant. However, the basicity increase leads to an increase in Sn recovery $[8,9]$. The change of basicity through the addition of Quartz has a significant effect during the reduction of cassiterite. The decrease of basicity on the $\mathrm{Sn}$ recovery has a negative impact. The addition of $\mathrm{SiO}_{2}$ leads to the formation of orthosilicate phases such as $\mathrm{SnSiO}_{3}[10]$. This may constitute barriers around $\mathrm{SnO}$ particles, that decreases its activity disturbing the reduction mechanism of $\mathrm{SnO}$ to $\mathrm{Sn}$ [2]. Figure 3 below summarizes the mechanism of reduction.

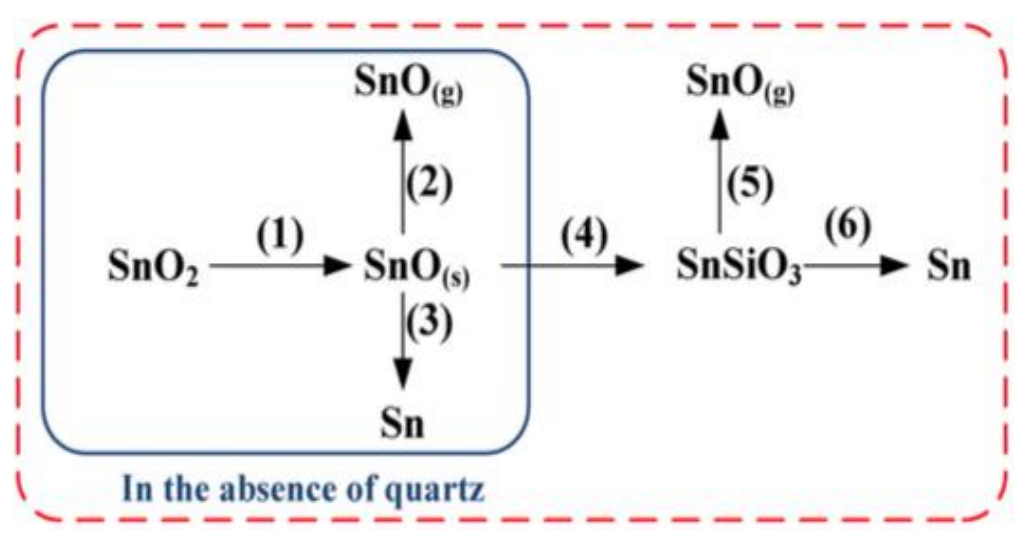

Figure 3 Influence of $\mathrm{SiO}_{2}$ on tin production [2]

\subsection{Effect of carbon content during reduction smelting of cassiterite}

The carbothermic reduction is the most known and popular method used in the smelting of Sn from cassiterite concentrates. This technique is applied on the Sn concentrate at temperature range $1200-1300{ }^{\circ} \mathrm{C}$ while 
adding fluxes $\left(\mathrm{CaCO}_{3}, \mathrm{SiO}_{2}\right)$ with the objective of producing an alloy containing $50-91 \% \mathrm{Sn}$. The smelting process takes place according to reaction 14 .

$2 \mathrm{SnO}_{2}+3 \mathrm{C}=2 \mathrm{Sn}+2 \mathrm{CO}+\mathrm{CO}_{2} . \quad(\Delta \mathrm{G}=210 \mathrm{~kJ} / \mathrm{mol})$

A series of previous studies have investigated on the use of carbon or carbon compounds such as $\mathrm{CaCO}_{3}$, $\mathrm{Na}_{2} \mathrm{CO}_{3}, \mathrm{~K}_{2} \mathrm{CO}_{3}$ during smelting process of cassiterite and columbotantalite mining tailings fluxed with borax while using graphite. A Sn metal of $96 \%$ purity was obtained using $\mathrm{CaCO}_{3}$ as flux. It had about $25 \%$ of mass recovery compared to the feed concentrate while containing $45 \%$ of the overall $\mathrm{Nb}_{2} \mathrm{O}_{5} / \mathrm{Ta}_{2} \mathrm{O}_{5}[1]$.

Furthermore, the effect of carbon was also investigated on the reduction of $\mathrm{SnO}_{2}$ from the anodic slime to produce a molten Sn. Han, et al., 2015 used a carbon source of 85 wt\% fixed carbon and $15 \%$ ash for the reduction process and found out that only $9 \mathrm{wt}$. \% coke was needed to reduce $\mathrm{SnO}_{2}$ slime to a high pure $\mathrm{Sn}$ metal at $1273 \mathrm{~K}$. The quality of carbon has a positive effect on both the temperature as well as the metal quality.

The use of a combination of charcoal with $\mathrm{Na}_{2} \mathrm{CO}_{3}-\mathrm{NaNO}_{3}$ on the reduction process of Egyptian cassiterite concentrate at temperature ranging $850-1000^{\circ} \mathrm{C}$ was investigated. It was found that for 60 minutes of smelting, a Sn metal of $95 \%$ purity was obtained at $1000{ }^{\circ} \mathrm{C}$ further purification of Sn metal led to $99.6 \%$ [10].

The kinetics of the reduction reactions during the smelting of $\mathrm{Sn}$ oxide can be evaluated from the ratio of oxygen mass which is removed from the original sample over the total oxygen mass before any reduction process [3].

The effect of carbon from a gaseous source $(\mathrm{CO})$ on the pretreated $\mathrm{Sn}$ compound at lower temperature was also investigated. The $\mathrm{SnO}_{2}$ mineral was mixed with a salt of $\mathrm{Na}_{2} \mathrm{CO}_{3}-\mathrm{NaNO}_{3}$ in the ratio of 1:0.3 to form an intermediate compound of $\mathrm{Na}_{2} \mathrm{SnO}_{3}$. After smelting for $1.5 \mathrm{hrs}$ in the temperature range $600-950{ }^{\circ} \mathrm{C}$ while blowing CO gas, a Sn metal with $97 \%$ purity was obtained from the cassiterite concentrate [11].

In order to control the reduction rate, $\mathrm{MgO}$ content needs monitoring [3]. Due to the presence of $\mathrm{K}_{2} \mathrm{CO}_{3}, \mathrm{SiO}_{2}$, $\mathrm{Al}_{2} \mathrm{O}_{3}$ and $\mathrm{CaO}$ the activation energy is reduced. The addition of $\mathrm{MgO}$ content during the reduction process has has a catalytic effect on the Boudouard reaction.

The conversion of $\mathrm{SnO}_{2}$ into metal was found to be function of particle size, the type of reductant used, temperature and reaction time. It was noticed that effectiveness of collie coal was due to its high reactivity and its low ash content when compared to metallurgical coke [12].

During smelting it is important to well manage the slag. The saying:" look at the slag and the metal will look at it itself" is paramount. The viscosity of the slag and melting temperature of the slag are key for better slag/metal separation. The better the immiscibility of the two phases, the less metal carried or entrapped in the slag phase $[13,14]$.

\subsection{Effect of time on phase formation in the slag during tin production}

The reduction time plays an important role on the formation of phases dissolving some metals. In case the tin ore contains $\mathrm{Nb}$ and Ta oxides, at constant basicity, while varying reduction time at same working temperature, $\mathrm{Nb}$ and $\mathrm{Ta}$ are dissolved in monticellite, ferrocolumbite and fayalite. Tantalum oxide and Niobium oxide may reach $5 \%$ in the slag while the purity of metal reached a maximum of $99 \%$ of $\mathrm{Sn}$ and $1 \% \mathrm{Fe}$. This makes the slag of considerable value [9].

\section{CONCLUSION}

Due to increasing demand of tin and its by-products, several parameters have to be considered based on the mineralogical composition of the ore. $\mathrm{FeO} / \mathrm{SnO}$ ratio plays a critical role if a two-stage production flow sheet is adopted since the primary and secondary slag has an impact on tin recovery. $\mathrm{Fe}_{3} \mathrm{O}_{4}$ presence may reduce $\mathrm{Sn}$ 
recover because of the formation of a spinel phase. $\mathrm{Fe}_{3} \mathrm{O}_{4}$ removal prior to the smelting is recommended. The basicity change through the addition of quartz decreases $\mathrm{Sn}$ recovery due to the formation of orthosilicates phases that decrease the activity of tin oxide while $\mathrm{CaO}$ addition improves $\mathrm{Sn}$ recovery coupled with formation of phases that collect $\mathrm{Nb}$ and Ta oxides if present in the ore. Roasting is key to improve Sn recovery The use of $\mathrm{Na}_{2} \mathrm{CO}_{3}$ has an impact on the slag formation by displacing $\mathrm{SiO}_{2}$ that react with sodium carbonate to free tin oxide that consequently is efficiently reduced. In addition, the particle size plays also a critical role in the recovery of tin.

\section{ACKNOWLEDGEMENTS}

\section{The author thanks all the colleagues for constructive discussion and contributions during the drafting of this paper to enhance the production of tin.}

\section{REFERENCES}

[1] LOPEZ, F.A., DIAZ, I.G., LARGO, O.R., POLONIO, F.G., LIORENS, T. Recovery and purification of tin from Tailings from the Penouta Sn-Ta-Nb deposit. Minerals. 2018, vol. 20, no. 8, pp. 1-13.

[2] ZHANG, Y., LIU, B., SU, Z., CHEN, J., LI, G., JIANG, T. Effect of $\mathrm{Na}_{2} \mathrm{CO}_{3}$ on the preparation of metallic tin from cassiterite roasted under strong reductive atmosphere. Journal of mining and metallurgy, section B: Metallurgy. 2016, vol. 52, no. 1, pp. 09-15.

[3] DEVENTER, V. The effect of admixtures on the reduction of cassiterite by graphite. Thermochimica Acta. 1988, vol. 124, pp. 109-118.

[4] ALFONSO, P., OliVA, J., GARCIA-VAlLES, M., TOMASA, O., CALVO, D., GUASCH, E., PARCERISA, D. Mineralogical characterisation of tantalum ores for the optimization of their processing. International Journal of Mining, Materials and Metallurgical Engineering. 2016, vol. 2, pp. 20-24

[5] YOUSSEF, M., ABD EL-RAHMAN, M., HELAL, N., EL-RABIEI, M., ELSAIDY, S. Optimization of shaking table and dry magnetic separation on recovery of Egyptian placer cassiterite using experimental design technique. Journal of Ore Dressing. 2009, vol. 11, no. 22, p. 1.

[6] UYS, H. A. The metallurgy of tin smelting in a submerged-arc furnace. Journal of the South African Institute of Mining and Metallurgy. 1977, pp. 121-125.

[7] SU, Z., ZHANG, Y., LIU, B., ZHOU, Y., JIANG, T., LI, G. Reduction behavior of $\mathrm{SnO}_{2}$ in the tin-bearing iron concentrates under $\mathrm{CO}-\mathrm{CO}_{2}$ atmosphere. Part I: Effect of magnetite. Powder Technology. 2016, vol. 296, pp. 251-259.

[8] SEEMA, M.C., KALENGA, M., NHETA, W. Effect of $\mathrm{CaO} / \mathrm{MgO}$ ratio and basicity during tin smelting on the metal and slag formation (II). Proceedings of XIX th International Multidisciplinary Scientific GeoConference SGEM 2019. Varna, Bulgaria, 2019, 28 June - 7 July, pp. 785-791.

[9] MUTOMBO, D, KALENGA, M. and NHETA, W. Effect of $\mathrm{CaO} / \mathrm{MgO}$ ratio on the product quality during tin smelting. Proceedings of the $4^{\text {th }}$ World Congress on Mechanical, Chemical and Material Engineering (MCM18). Madrid, Spain, August 16-18, 2018, pp. 122-126.

[10] EL DEEB, A.B. Pyrometallurgical extraction of tin metal from the Egyptian cassiterite concentrate. International Journal of Scientific \& Engineering Research. 2015, vol. 6, no. 3, pp. 54-64.

[11] KOMKOV, V.G., GOSTRSHCHEV, V.V., Ri, E.Kh. Physiochemical Aspects of Carbothermic reduction of cassiterite in the ionic melts. Metallurgy of Nonferrous Metals. 2009, vol. 50, no. 6, pp. 596-599.

[12] MUDZANAPABWE, N.T., CHINYAMAKOBVU, O.S., SIMBI, D.J. In situ carbothermic reduction of ferro-colombite concentrate in the recovery of $\mathrm{Nb}$ and $\mathrm{Ta}$ as metal matrix composite from tin smelting slag waste dump. Materials Design. 2004, vol. 25, pp. 297-302.

[13] MILLS, K.C., FOX, A.B. The role of mould fluxes in continuous casting. So simple yet so complex. ISIJ International. 2003, vol. 43, no. 10, pp. 1479-1486.

[14] MILLS, K.C., YUAN, L., JONES, R.T. Estimating the physical properties of the slags. The Journal of the Southern African Institute of Mining and Metallurgy. 2011, vol. 111, pp. 649-658. 